\section{The epidemiologic transition in Peru}

\author{
Maud M. T. E. Huynen, ${ }^{1}$ \\ Laura Vollebregt, ${ }^{1}$ Pim Martens, ${ }^{1}$ \\ and Bruno M. Benavides ${ }^{2}$
}

Key words: health transition, risk factors, cause of death, health services accessibility, Peru.

\footnotetext{
Maastricht University, International Centre for Integrative Studies, Maastricht, the Netherlands. Send correspondence to: Maud Huynen, International Centre for Integrative Studies, Maastricht University, P.O. Box 616, 6200 MD Maastricht, the Netherlands; e-mail: m.huynen@icis.unimaas.nl; telephone: +31-43-3884840; fax: +31-433884916.

2 Partners in Population and Development, Dhaka, Bangladesh.
}

In 1971, Omran formulated the epidemiologic transition theory (1), which builds on the demographic transition theory but also includes the changing patterns in diseases and the causes of death. He recognizes that the epidemiologic transition of nonindustrialized societies differs fundamentally from the epidemiologic transition in the developed (Western) world (2). Omran's non-Western transition model describes the epidemiologic changes over time in developing countries in terms of three stages: "the age of pestilence and famine," "the age of receding pandemic," and "the age of triple health burden" (2). This paper explores the epidemiologic transition in Peru.

Peru is situated in western South America, between Chile and Ecuador and bordering the Pacific Ocean. Peru has a population of 27 million people (3) and a total area of $1285215 \mathrm{~km}^{2}$ (4). There have been some major changes in the country's health situation in recent decades. For example, average life expectancy at birth increased from about 44 years in the early 1950s to almost 70 years in 2002 (5). Also making Peru an interesting case study is the fact that the country has three totally different geographical regions: the coast (costa), the Andean highlands (sierra), and the Amazon jungle (selva). These regions differ from each other with regard to their ecological systems and climate, their socioeconomic status, and their culture. Peru has 25 departments, which are the country's main administrative units. These departments are categorized into five poverty strata, with stratum I being the richest and stratum $\mathrm{V}$ the poorest (6) (Table 1). The richest departments are in the coastal region. Peru's diversity in geography and economic status is also reflected in a diversity in health status within the country.

For this study six key Peruvian experts were interviewed and an extensive literature and data search was conducted in order to obtain relevant information on the past and present health situation in Peru. With respect to the availability of both historical health data and current health data, it is important to note that Peru has had an incomplete registration of health information. For example, estimates of mortality before 1950 are difficult to obtain, and current mortality rates are still corrected for underregistration, since nearly $50 \%$ of all deaths in Peru go unregistered (4). However, the Pan American Health Organization (PAHO) concluded in 1962 that the available mortality data still gave a sufficient basis for assessing the main problems and 
TABLE 1. The five poverty strata in Peru

\begin{tabular}{|c|c|}
\hline $\begin{array}{l}\text { Poverty } \\
\text { stratum }^{\mathrm{a}}\end{array}$ & Departments \\
\hline I & Tacna, Lima, Callao \\
\hline II & $\begin{array}{l}\text { Moquegua, La Libertad, Lambayeque, Ica, } \\
\text { Arequipa }\end{array}$ \\
\hline III & $\begin{array}{l}\text { Ucayali, San Martín, Piura, Junín, Ancash, } \\
\text { Tumbes }\end{array}$ \\
\hline IV & $\begin{array}{l}\text { Pasco, Huánuco, Cuzco, Loreto, Cajamarca, } \\
\text { Amazonas, Madre de Dios, Puno }\end{array}$ \\
\hline V & Huancavelica, Ayacucho, Apurímac \\
\hline
\end{tabular}

Source: Perú, Ministerio de Salud, 2001 (6).

a Stratum I is the richest and stratum V is the poorest.

trends in the country's health status (7), and the information systems and estimates have been improving ever since.

The first part of this paper describes the observed developments in fertility, population, overall mortality, mortality from infectious diseases, mortality from noncommunicable diseases, and the health care system. This paper focuses on the diversity in the health situation in Peru, using the concept of epidemiologic polarization. Epidemiologic polarization refers to a process in which unequal distributions in wealth, health risks, and health services result in increasing differences in health status within a population and a widening "health gap" between the poor and the rich. The paper also assesses whether the "protracted polarized transition model" (8) can be applied to the epidemiologic changes that have occurred in Peru.

\section{THE EPIDEMIOLOGIC TRANSITION IN PERU}

Peru has experienced a significant decline in the mortality rate, from 21.6 deaths per 1000 inhabitants in 1950-1954 to 6.4 deaths per 1000 inhabitants in 1995-1999 (Figure 1) $(3,9)$. There has also been an enormous decline in the infant mortality rate, from almost 159 per 1000 live births in 1950-1954 to 42 per 1000 live births in 1995-1999 (3). Maternal mortality has also declined, from 399 women per 1000000 live births in 1970 (9) to 165 women per 100000 live births in 1994-2000, but Peru still has one of the highest figures among the countries of Latin America (10).

Another change of great importance in Peru has been the decline in the fertility rate. Between the beginning of 1950 and the end of 1964 the total fertility rate was estimated to be at a high level (with it being 6.85 children per woman in 19601964). Fertility declined slightly to an average of 6.56 children per woman in 1965-1969. After 1969 the decline accelerated, falling to 4.65 for 1975-1979, 4.10 for 1985-1989, and 3.20 for 1995-1999 (Figure 2) $(3,11)$.

Due to the fact that mortality started to decline before fertility did in Peru, an increase in the population growth rate occurred. In the 1940s the average population growth was below $2.0 \%$ (7), but this increased to $2.8 \%$ in the late $1960 \mathrm{~s}$. As expected, this growth rate started to decrease again after the onset of the fertility decline in the early 1970s, falling to an average population growth of $1.7 \%$ in the late 1990s (3).

In terms of the causes of death in the period of $1970-1974,44.2 \%$ of all deaths were due to infec-

FIGURE 1. Crude mortality rate (per 1000 ) in Latin America and the Caribbean vs. Peru, 1950-1999

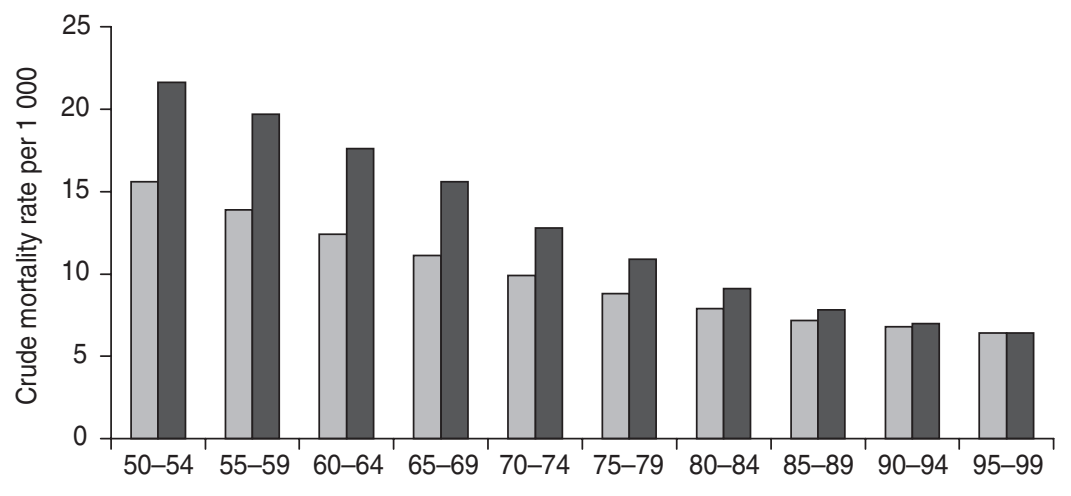

Five-year period

$\square$ Latin America and the Carribean $\quad \square$ Peru

Source: United Nations. World population prospects, 2003 (3). 
FIGURE 2. Fertility rate (children per woman) in Latin America and the Caribbean vs. Peru, 1950-1999

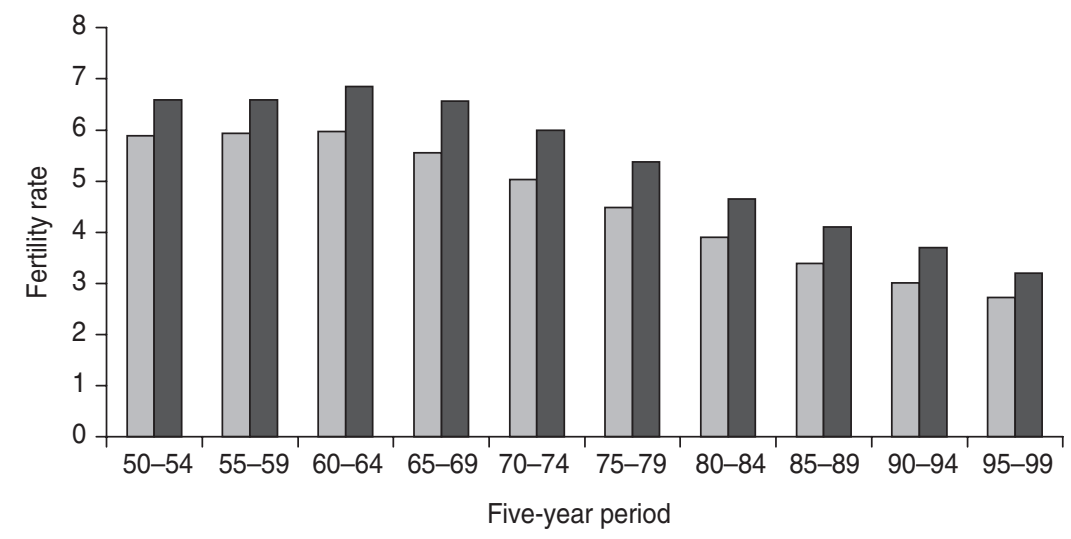

$\square$ Latin America and the Carribean $\square$ Peru

Source: United Nations. World population prospects, 2003 (3).

tious and parasitic diseases (9). In 1992, acute respiratory infections still accounted for $16.3 \%$ of all deaths, while intestinal infectious diseases caused $7.7 \%$ of total mortality (12). There was a decline in mortality from communicable causes from 247.5 deaths per 100000 in 1987 (4) to 145.7 deaths per 100000 in 1996-1998 (13) and 130.3 deaths per 100000 in the year 2000 (14). Nonetheless, communicable diseases are still the leading cause of death, and acute respiratory infections are the most frequent killers of them all $(4,12,13)$. Among children aged 0-4 years, communicable diseases are the most important cause of death, with respiratory infections and intestinal infectious diseases accounting for $86 \%$ of total mortality (4).
There has also been a reemergence of some other communicable diseases in Peru. For example, the overall prevalence of tuberculosis declined in the 1960s and 1970s, to approximately 100 cases per 100000 inhabitants (10), but after 1985 the number of cases increased rapidly, reaching 256.1 cases per 100000 in $1992(9,12,15)$. However, the availability of data was very poor before 1990, and it is possible that the large increase observed between 1985 and 1992 is biased by this previous lack of reliable data. After 1992 a downward trend in tuberculosis cases set in, with morbidity rates just below 200 per 100000 in 1996 (12) and about 155 per 100000 in $2000(4,15)$ (Figure 3). In the early 1990s, the outbreak of cholera was a major public health emer-

FIGURE 3. Tuberculosis morbidity rate per 100 000, Peru, 1987-2000

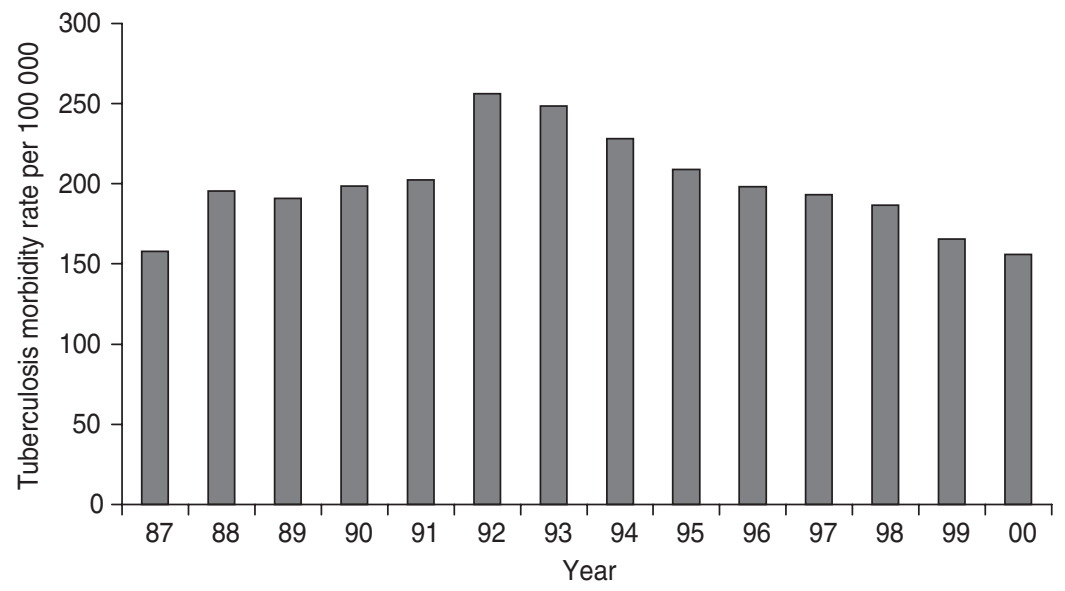

Source: Perú, Instituto Nacional de Estadística e Informática, 2001 (15). 
gency. In 1991, 322562 Peruvians fell sick and 2909 died of the disease (16). Fortunately, cholera has been declining ever since, to 934 cases in 2000, with the exception of 1998, when the effects of the El Niño weather phenomenon caused a total of 42000 cases (4).

Vector-borne diseases are also still major problems for public health in Peru. Three important infectious diseases caused by vector-borne parasites in Peru are dengue fever, yellow fever, and malaria, which are all transmitted by mosquitoes. Although many mosquito control programs were undertaken in earlier decades, a reemergence of these diseases has occurred. For example, the vector responsible for dengue fever was eradicated in 1958 (9), but the disease reemerged in 1990, when more than 9600 cases were reported (12). In 2000, Peru had an average dengue prevalence rate of 21.4 per 100000 inhabitants, but some areas showed much higher figures (13).

Peru has experienced a large increase in internal migration and an extensive conversion of jungle land into agricultural and industrial areas. These trends contributed to epidemic proportions of yellow fever, with 503 cases being reported in 1995, with a case fatality rate of $38.8 \%$. Intensification of vaccination activities successfully reduced the incidence to 86 cases, with 34 deaths, in 1996 (12).

In the past, Peruvian campaigns against malaria were extensive and achieved noticeable results. In the 1960s there were very few cases of malaria (e.g., 16 cases per 100000 in 1965), but since the 1970s, and especially since 1990, the situation has worsened $(9,12,15,17)$ (Figure 4). A number of factors have contributed to the reemergence of this disease. These factors include extensive internal mi- gration, the development of new irrigated areas for rice and cotton farming, the spread of the vector, difficulties in managing the control program in hard-to-reach areas, difficulties created by illegal drug activities in the jungle, and the massive number of cases in the neighboring countries of Ecuador and Colombia. In 1996 there were about 885 cases per 100000 in Peru, and in 1998 an even higher 997 per 100000 (this latter figure probably due in part to the effects of El Niño) $(12,15,17)$. The reemergence of the disease resulted in the intensification of malaria control programs (12), and in 2000 the rate for all types of malaria declined to 266.2 cases per 100000 (15). The proportion of malaria caused by Plasmodium falciparum, which is responsible for the most lethal kind of malaria, increased from $19.7 \%$ in 1995 to $41.6 \%$ in 1999 , but then declined to $30.2 \%$ in 2000 (4).

Since the first case of AIDS was reported in Peru in 1983 (12, 15), HIV / AIDS has been spreading throughout the country. In 2000 the incidence rate of AIDS in the country was 36.6 cases per 1000000 population, although it is more prevalent in the larger cities, particularly in Lima and Callao (13). The number of persons infected with HIV is many times higher (10).

Noncommunicable diseases are an increasingly important public health problem in Peru, especially in the urban regions of the country (18). Figures for 1994-1998 show that diseases of the circulatory system, tumors, and traumas are together responsible for $40 \%$ of the deaths in Peru (9). In 1967, diseases of the circulatory system accounted for only $5.4 \%$ of all deaths from defined causes (19). In 1994-1998, cardiovascular diseases were responsible for $16.3 \%$ of all deaths in Peru (9). In 1996-1998

FIGURE 4. Malaria incidence rate (registered cases per 100 000), Peru, 1960-2000

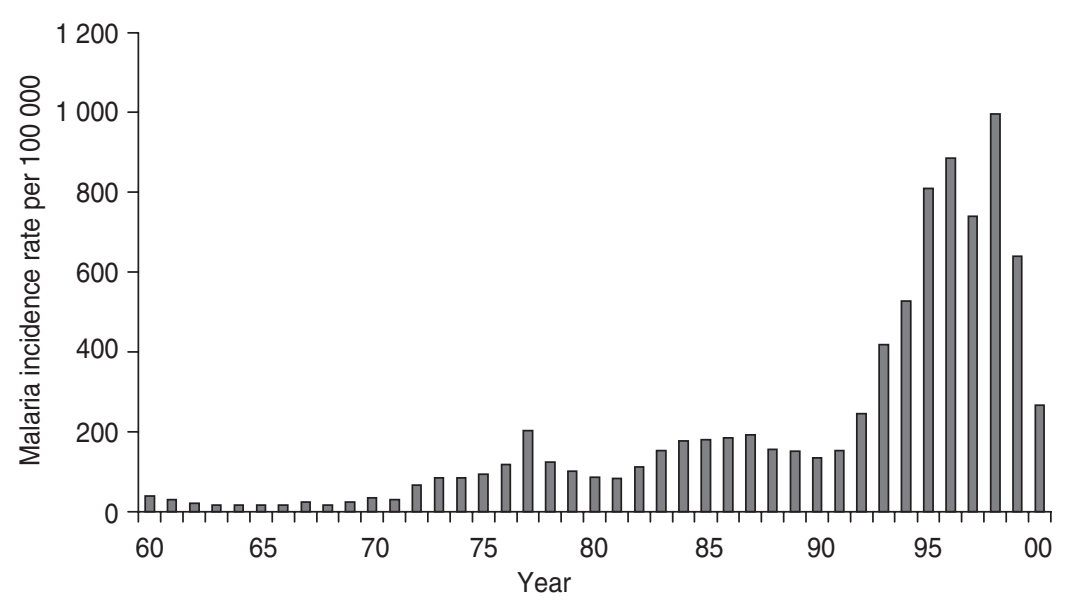

Source: Perú, Instituto Nacional de Estadística e Informática, 2001 (15) and Perú, Instituto Nacional de Estadística e Informática, 2000 (17). 
the mortality rate for cardiovascular diseases was 89.1 per 100000 (13). Among the elderly, diseases of the circulatory system are the primary cause of death (12).

In 1972 only $5.6 \%$ of total mortality was attributable to tumors (9), but this proportion reached $14.2 \%$ in 1997 (4). In 1996-1998 the mortality rate for malignant diseases was 93.8 per 100000 (4). There are, however, important variances between the different forms of cancer. In females the frequency of breast cancer has increased, while cervical cancer decreased between 1968 and 1991. In males in the same period, mortality from stomach cancer decreased, but mortality from prostate cancer increased (12).

The prevalence of unhealthy lifestyles is also increasing in Peru. In 1998, 44.5\% of the population between 12 and 64 years old had consumed tobacco during the preceding year, and $79.6 \%$ had consumed alcohol (20). Preobesity prevalence is very high in most Latin American countries, and 53\% of the Peruvian population has a body mass index (BMI) higher than $25 \mathrm{~kg} / \mathrm{m}^{2}$ (21). About $34 \%$ of Peruvian women aged 15-49 years are overweight $(25 \leq \mathrm{BMI}<30)$, and $13 \%$ are obese $(\mathrm{BMI} \geq 30)(22)$. Smoking, alcohol consumption, and obesity are all related to the development of cardiovascular diseases and malignant diseases.

In Peru, lack of access to health care facilities is an increasing problem, especially for the poor. The percentage of people insured in 1997 ranged from $35.9 \%$ in metropolitan Lima to only $6.2 \%$ in the rural areas (20). Of the insured people in 1997, $86.5 \%$ of them were affiliated with the Social Security system, and $6.8 \%$ of them relied solely on private insurance (20). In terms of health care facilities, the number of hospitals has fluctuated in recent decades, although these figures can be influenced by the lack of clear criteria to categorize health facilities. There were reportedly 210 hospitals in 1959 (7), 435 in 1972 (23), 353 in 1986, and 488 in 2000 (15). In 1959 the number of hospital beds was 2.2 per 1000 persons (7). This increased slightly by 1968 , reaching 2.4 per 1000 population (19), but fell back to about 1.2 per 1000 by 1992 (12). Over that same period there was a concomitant increase in the provision of basic health services and primary care (9), with the number of health centers and posts doubling in the 1980s $(9,24)$. After the 1990 elections the health sector priorities of the new government were also focused on primary care services. There was a $61 \%$ increase in primary health care facilities between 1992 and 1995, but the number of hospital beds only rose to 1.3 per 1000 inhabitants (12). The increase in the number of primary care centers in the 1990s was primarily due to the implementation of new health programs, including the Social Ex- pense Targeting Program (Programa de Focalización del Gasto Social) and the Basic Health for All Program (Programa Salud Básica para Todos). In 1997, $31 \%$ of the Ministry of Health budget went to hospitals, and $62 \%$ went to health centers and health posts (4). In 1999 the public sector provided for $99 \%$ of all health posts, $69 \%$ of all health centers, and $51 \%$ of all hospitals (20). The numbers of physicians, professional nurses, and dentists have been increasing, respectively reaching $10.3,6.7$, and 1.1 per 10000 population in 1996 (4). Unfortunately, medical staff and hospital beds are mostly concentrated in cities and in the most developed regions and departments (12).

The information presented above indicates that the changes in the Peruvian health situation are a good example of the non-Western transition model. The mortality decline in Peru largely took place in the second half of the 20th century, while fertility did not start to decline seriously until after 1970. Therefore, the second phase of this modelthe age of receding pandemics - can be placed between the mid-20th century and approximately 1970. Peru is now clearly in the third stage of the non-Western model, with the country experiencing a triple health burden. First, there are unfinished old health problems like "old-fashioned" infectious diseases (e.g., acute respiratory diseases and intestinal infections) and high maternal mortality rates. Second, new health problems are arising: Cardiovascular diseases and malignant neoplasms have become important causes of death, old diseases are reemerging (e.g., malaria), and new diseases are appearing (e.g., HIV/AIDS). Drug resistance is a problem in the fight against tuberculosis and other diseases. An ill-prepared health system is the third important feature of the age of triple health burden. Peru faces problems regarding the availability of health services (in terms of facilities and medical staff) as well as a low percentage of inhabitants who are insured.

\section{EPIDEMIOLOGIC POLARIZATION}

Peru is a very diverse country, and its diversity is reflected in its geographical and socioeconomic regions. It is, therefore, expected that this diversity is also reflected in the health status within the country. According to Frenk et al. (8), the duration and timing of the epidemiologic transition in a given country reflects an average of diverse transitions within the country, occurring in different social groups and different regions. This can result in epidemiological polarization, when the duration and timing of these diverse epidemiological transitions within a country differ significantly due to 
TABLE 2. Epidemiological polarization in Peru, as shown by health indicators for the departments of Lima and Huancavelica

\begin{tabular}{|c|c|c|}
\hline Determinant/Year & Lima & Huancavelica \\
\hline Region $(N A)^{a}$ & Costa & Sierra \\
\hline Poverty stratum (NA) & I (richest) & V (poorest) \\
\hline Poverty (\% of inhabitants) $(2002)^{b}$ & 35.8 & 83.7 \\
\hline Extreme poverty (\% of inhabitants) $(2002)^{b}$ & 3.9 & 61.6 \\
\hline Urban population (\% of inhabitants) $(2003)^{\mathrm{b}}$ & 97.3 & 27.0 \\
\hline Chronic malnutrition $\left(\%\right.$ of inhabitants aged $<5$ years) $(2000)^{\mathrm{b}}$ & 8.3 & 53.4 \\
\hline Illiteracy rate $\left(\%\right.$ of inhabitants) $(2000)^{\mathrm{b}}$ & 3.9 & 17.5 \\
\hline Life expectancy at birth (years) $(1995-1999)^{c}$ & 76.8 & 56.8 \\
\hline Crude mortality rate per $1000(1995-1999)^{c}$ & 4.1 & 13.0 \\
\hline Total fertility rate (children per woman) $(2000)^{b}$ & 2.1 & 6.1 \\
\hline Communicable diseases: mortality rate per 100000 population $(2000)^{b}$ & 88.6 & 239.6 \\
\hline Diseases of circulatory system: mortality rate per 100000 population $(2000)^{b}$ & 79.6 & 165.2 \\
\hline Malignant neoplasms: mortality rate per 100000 population $(2000)^{b}$ & 93.8 & 123.2 \\
\hline Physicians per 100000 inhabitants $(1996)^{d}$ & 18.9 & 2.8 \\
\hline Number of hospital beds per 1000 inhabitants $(1996)^{d}$ & 2.4 & 1.5 \\
\hline
\end{tabular}

$\mathrm{NA}=$ not applicable

b Source: Perú, Ministerio de Salud, 2003 (14).

c Source: Perú, Instituto Nacional de Estadística e Informática, 2000 (25).

d Source: Perú, Ministerio de Salud, 2001 (13).

very unequal distributions in such things as wealth, health risks, and health service. Table 2 shows the differences in health indicators in the Peruvian departments of Lima and Huancavelica. These two departments are chosen to represent the polarization within the country. Lima (poverty stratum I (richest)) is in the coastal region and has a relatively low percentage of poor people, while Huancavelica (poverty stratum V (poorest)) is a rural department in the mountain region and has a relatively high percentage of poor people. There are also great differences between these two departments regarding important health determinants such as chronic malnutrition in children (measured as stunting) and the illiteracy rate $(13,14,25)$ (Table 2$)$.

Table 2 shows that the departments of Lima and Huancavelica differ greatly regarding important health indicators. The difference in life expectancy at birth for the 1995-1999 period was 20 years: 76.8 years in Lima vs. 56.8 years in Huancavelica. The crude mortality rate and the fertility rate are also much higher in Huancavelica $(14,25)$. In 1996-1998, infectious diseases still resulted in more deaths in Huancavelica than did malignant neoplasms and cardiovascular diseases together. In Lima, however, communicable diseases caused less mortality than did malignant and cardiovascular diseases (13). Table 2 also shows that infectious diseases were still the most frequent cause of death in Huancavelica in 2000, while in Lima the mortality rate was the highest for malignant diseases (14). Similar patterns could be seen when comparing the causes of death in 1992 in all of the richest, stratum I departments of the country with the causes in all of the poorest, stratum V departments (12). In the richest departments, diseases of the circulatory system, malignant neoplasms, and infectious diseases accounted for respectively $22.1 \%, 19.3 \%$, and $21.5 \%$ of all deaths. In the poorest departments, the figures were respectively $10.2 \%, 4.6 \%$, and $44.0 \%$.

Health system capacity also differs between Lima and Huancavelica (Table 2). In 1996 the number of hospital beds per 1000 inhabitants was 2.4 in Lima and 1.5 in Huancavelica. The difference is even more extreme if one looks at the number of physicians. In 1996, Lima had 18.9 physicians per 100000 inhabitants, while Huancavelica had only 2.8 physicians per 100000 inhabitants (13). No information is available about the number of people with health insurance in these two departments. However, in 1997 the percentage of insured people was almost six times higher in metropolitan Lima than in the rural areas of Peru (20).

Table 2 clearly shows that the epidemiologic transition has advanced further and that the health care system is more developed in richer Lima than in poorer Huancavelica. We could reach similar conclusions by comparing other richer departments of the country with other poorer ones. Due to this wide variety in the health situation and in the health system capacity within the country, the protracted polarized transition model could be applicable to the epidemiologic changes in Peru, as is explained in the next section. 


\section{THE PROTRACTED POLARIZED MODEL}

Frenk et al. (8) proposed the protracted polarized model in order to account for the differences in health developments among the different social groups and the different regions within a country. According to Bobadilla et al. (26), the protracted polarized model has five main features. All of these features are found in Peru, as described in the next five paragraphs.

The first feature of the protracted polarized model is that the period of time in which mortality decline takes place is very short compared to Western countries. In Peru the mortality decline took place over a very short period of time in comparison to what happened in the countries of the West. In Peru the mortality rate was 21.6 per 1000 inhabitants in 1950, but it was 6.4 in 1995-1999 (Figure 1). In the Western world, however, mortality slowly started to decline around 1750 . Mortality began to decline faster in the middle of the 19th century, but it took until the 20th century for it to reach low levels. The rate fell from more than 25 deaths per 1000 inhabitants in 1860 to fewer than 10 deaths per 1000 inhabitants around 1930 (27).

The second feature of the protracted polarized model is that mortality does not start to decline before the 20th century and that it reaches low levels near the end of that century. As already discussed, Peru has experienced a great decline in mortality since the mid-20th century. In the early 1980s the mortality rate fell below 10 per 1000 population, and at the end of the 20th century, mortality was relatively low, at 6.4 per 1000 (Figure 1).

The third feature is that infectious diseases are not yet brought fully under control and that although there are major reductions in the mortality caused by those diseases, the incidence rates are still relatively high at the end of the 20th century. This creates an overlap of stages, with a simultaneous increase in noncommunicable diseases. The overall incidence rate for infectious diseases in Peru is not available, but the mortality rate is still relatively high (130.3 deaths per 100000 in the year 2000) (14). At the same time, noncommunicable diseases have become an increasingly important public health problem.

The fourth feature of the protracted polarized model is that the distribution of wealth is very unequal and the coverage for health interventions is also incomplete. Because of these inequalities, the gap in health status among social classes and geographical regions is widening. In Peru, higher levels of economic development are found in the highly urbanized coastal regions, and income distribution within the country is very unequal. Be- tween 1997 and 2000 the income gap in Peru became even larger, with the ratio of the income of the richest quintile to that of the poorest quintile increasing from 4.9 to 7.8 (4). In addition, in the poorer regions there is a shortage of health care services as well as a higher percentage of uninsured persons. This inequality within the country is also reflected in important health indicators such as mortality, fertility, and causes of death. Between 1987 and the late 1990s there was even a widening of the gaps in mortality from intestinal diseases and infant mortality. Overall, the changes in the specific mortality profile (i.e., the relative importance of the different causes of death) reflect a widening of the mortality gap (4).

The fifth feature is that some of the epidemic diseases that had been controlled or eradicated in the past are reemerging and therefore producing a "countertransition." The reemergence of malaria and of tuberculosis is an important health problem in Peru (Figures 3 and 4), as are the recent epidemics of cholera, dengue, and yellow fever.

\section{CONCLUSIONS}

Peru has experienced important improvements in its health situation in recent decades, but the health gap between the rich and the poor is still a significant problem. That is, although the population in rural areas has become healthier, the urban population has by far remained the healthiest.

The Peruvian health situation is a good example of the non-Western transition model. Peru now finds itself in the third stage of this model, as the country is definitely struggling with a triple health burden. Peru has increased its life expectancy in a shorter period of time than did the nowindustrialized countries, thus leaving less time for the Peruvian health care system to adjust to the increasing problem of noncommunicable diseases. At the same time, the basic health facilities in some areas of Peru are not sufficient to adequately control the still-important, reemerging infectious diseases. The Ministry of Health has generally focused its resources on surveillance and control of infectious diseases, and it has not yet developed the health infrastructure needed to deal with the increase in noncommunicable diseases.

Like many other developing nations, Peru faces a major challenge. The course of infectious diseases and chronic diseases in the country will in part depend on the choices made by the Government, as it considers alternative health development strategies while proceeding through the health transition (28). The epidemiologic transition 
theory provides useful insights on past health developments and current health problems, and this knowledge can be applied in developing an integrated health strategy. In addition, understanding past epidemiologic changes is an ideal starting point for exploring the next phase in Peru's health transition. If rooted in knowledge about past and present developments, a proper analysis of health scenarios for Peru could make a meaningful contribution to the formulation of a sound and integrated health policy strategy for the country.

A complicating factor for Peru is the wide range and inequity in health status within the country. Any strategy to improve the health situation in Peru must include initiatives to narrow the health gap within the country. These initiatives have to include measures both to increase access to health care services among the poor and to decrease socioeconomic inequity overall. This would involve narrowing the gap among different social groups in terms of such important health determinants as income, education, nutrition, and health care. Closing the health gap requires new approaches that more effectively respond to the overall basic needs and interconnected problems that many disadvantaged persons face. Improving the health of all Peruvians will require major investments in public health, an integrated approach towards health by the Peruvian Government, and a strong commitment by the Ministry of Health and policymakers in health-related fields.

Acknowledgements. We would like to thank Marcos Cueto (Universidad Peruana Cayetano Heredia), Carlos Eduardo Aramburú (Consorcio de Investigación Económica y Social), Walter Mendoza de Souza (Instituto de Investigación Nutricional), Carlos Bardález del Aguila (Universidad Peruana Cayetano Heredia), Patricia Mostajo (Futures Group), and Magdalena Chú Villanueva (Asociación Peruana de Demografía y Población) for their valuable participation in the interviews. Furthermore, we would like to thank all our colleagues at the International Centre for Integrative Studies at Maastricht University for their help in finalizing this paper. This work is carried out as part of a Friedrich Wilhelm Bessel Research Award and is financially supported by the Dutch National Institute for Public Health and the Environment (RIVM) within the Globalisation, Environmental Change and Public Health project.

\section{SINOPSIS}

\section{La transición epidemiológica en el Perú}

En el presente trabajo se examina la transición epidemiológica en el Perú y se demuestra que los cambios observados en la situación de salud del país constituyen un buen ejemplo del modelo de transición no occidental que describe los cambios epidemiológicos producidos a lo largo del tiempo en países en desarrollo en función de tres etapas. Actualmente el Perú se encuentra en la tercera etapa de este modelo y tiene una carga de morbilidad que abarca tres componentes. Tiene, en primer lugar, problemas antiguos que aún no se han resuelto, como el de las enfermedades infecciosas "tradicionales" (por ej., las infecciones respiratorias agudas) y el de las elevadas tasas de mortalidad materna. También tiene, en segundo lugar, algunos problemas que apenas empiezan a aflorar: las enfermedades cardiovasculares y las neoplasias malignas se están incrementando, el paludismo y otras enfermedades más antiguas están reapareciendo, y la infección por VIH y el sida, más algunas otras enfermedades, han surgido por primera vez. En tercer lugar, el Perú adolece de una poca disponibilidad de buenos servicios de salud. En este contexto, el presente trabajo examina la gran falta de equidad en el Perú en lo concerniente a algunos indicadores de salud importantes (por ej., la esperanza de vida, la tasa de mortalidad, la tasa de fecundidad, y el acceso a seguro médico y a servicios de salud), a la luz del concepto de "polarización epidemiológica". Este último es un proceso según el cual la distribución desigual de la riqueza, de los riesgos de salud, y de los servicios de atención sanitaria redunda en diferencias cada vez mayores en el estado de salud de una población, y en una "brecha de salud" que se ensancha progresivamente entre pobres y ricos. Demostramos que la situación de salud del Perú ilustra todas las características del modelo de transición polarizada y prolongada, que es una variante del modelo de transición no occidental y que explica este proceso de polarización epidemiológica. Para hacerle frente a la triple carga de morbilidad y la polarización epidemiológica en el Perú, es necesario distribuir más uniformemente el desarrollo social y económico, procurando reducir la brecha entre ricos y pobres en lo referente a algunos factores determinantes destacados (por ej., el ingreso, la educación, la nutrición y los servicios de salud). Todo esto se conseguirá solo mediante grandes inversiones en la salud pública, la adopción de un enfoque integral por el Gobierno peruano, y el completo compromiso del Ministerio de Salud y de los formuladores de las políticas de salud y de otras áreas.

Palabras clave: transición de la salud, factores de riesgo, causa de muerte, accesibilidad a los servicios de salud, Perú. 


\section{REFERENCES}

1. Omran AR. The epidemiologic transition: a theory of the epidemiology of population change. Milbank Meml Fund Q. 1971;49(4):509-38.

2. Omran AR. The epidemiologic transition theory revisited thirty years later. World Health Stat Q. 1998;51(2-4):99119.

3. United Nations. World population prospects: the 2002 revision. New York: UN, Department of Economic and Social Affairs, Population Division; 2003.

4. Pan American Health Organization. Health in the Americas, 2002 edition. Washington, D.C.: PAHO; 2002.

5. World Health Organization. World health report 2004: changing history. Geneva: WHO; 2004.

6. Perú, Ministerio de Salud. Análisis de la situación de salud en el Perú. Lima: Ministerio de Salud; 2001.

7. Pan American Health Organization Health conditions in the Americas, 19571960. Washington, D.C.: PAHO; 1962.

8. Frenk J, Bobadilla JL, Sepulveda J, Lopez-Cervantes M. Health transition in middle-income countries: new challenges for health care. Health Policy Plan. 1989;4(1):29-39.

9. Bardález del Aguila C. Salud de población. In: Consorcio de Investigación Económica y Social, ed. Políticas de salud 2001-2006. Lima: CIES; 2001. Pp. 165-212.

10. Bardález C. Salud de la población. Econ Soc. 2002;44(1):5-10.

11. Aramburú CE. Dinámica demográfica y política de población en el Perú. Paper presented at the IV Reunión Nacional sobre Población del Perú, 26-29 April 1995. Available from: http://www. alter.org.pe/pobdes/programa.htm. Accessed 10 May 2004.

12. Pan American Health Organization. Health in the Americas, 1998 edition. Washington, D.C.: PAHO; 1998.

13. Perú, Ministerio de Salud. Situación de salud en el Perú: indicadores básicos. Lima: Ministerio de Salud; 2001.

14. Perú, Ministerio de Salud. Situación de salud en el Perú: indicadores básicos 2003. Lima: Ministerio de Salud; 2003.

15. Perú, Instituto Nacional de Estadística e Informática. Perú: compendio estadístico, 2001. Lima: INEI; 2001.

16. Cueto M. The return of epidemics: health and society in Peru during the twentieth century. Aldershot: Ashgate; 2001.

17. Perú, Instituto Nacional de Estadística e Informática. Perú: compendio estadístico socio demográfico 1999-2000. Lima: INEI; 2000.

18. Perú, Ministerio de Salud. El desafío del cambio de milenio: un sector salud con equidad, eficiencia y calidad. Lima: Ministerio de Salud; 1996.

19. Pan American Health Organization Health conditions in the Americas, 19651968. Washington, D.C.: PAHO; 1970.

20. Pan American Health Organization. Health services system profile of Peru. Lima: PAHO /WHO/Catholic University of Peru; 2001.

21. Filozof C, Gonzalez C, Sereday M, Mazza M, Braguinsky J. Obesity preva- lence and trends in Latin-American countries. Obesity Rev. 2001;2(2):99-106.

22. Reyes J, Ochoa L. Encuesta Demográfica y de Salud-ENDES 2000. Lima: Instituto Nacional de Estadística e Informática; 2001.

23. Pan American Health Organization. Health conditions in the Americas, 1969_ 1972. Washington, D.C.: PAHO; 1974.

24. Perú, Instituto Nacional de Estadística e Informática. [Data on the number of health establishments.] Available from: http://www.inei.gob.pe. Accessed 24 January 2004

25. Perú, Instituto Nacional de Estadística e Informática. Las estadísticas vitales en los distritos del Perú. Lima: INEI; 2000.

26. Bobadilla JL, Frenk J, Frejka T, Lozano R Stern C. The epidemiologic transition and health priorities. In: Jamison DT, Mosley WH, Measham AR, Bobadilla JL, eds. Disease control priorities in developing countries. New York: Oxford University Press for the World Bank; 1993. Pp. 51-63.

27. McKeown T. The modern rise of population. London: Edward Arnold; 1976.

28. Mosley WH, Bobadilla JL, Jamison DT. The health transition: implications for health policy in developing countries. In: Jamison DT, Mosley WH, Measham AR, Bobadilla JL, eds. Disease control priorities in developing countries. New York: Oxford University Press for the World Bank; 1993. Pp. 673-99.

The biggest difficulty with mankind today is that our knowledge has increased so much faster than our wisdom.

[El mayor problema que enfrenta la humanidad hoy en día es que sus conocimientos superan, con mucho, su sabiduría.]

Frank Whitmore 